\section{A. Naseer, S. Naqvi and B. Kampmann}

Academic Dept of Paediatrics, Imperial College, London, UK.

\section{STATEMENT OF INTEREST}

None declared.

\section{REFERENCES}

1 Leyten EMS, Prins C, Bossink AWJ, et al. Effect of tuberculin skin testing on a Mycobacterium tuberculosis-specific interferon- $\gamma$ assay. Eur Respir J 2007; 29: 1212-1216.

2 National Institute for Health and Clinical Excellence. Tuberculosis: clinical diagnosis and management of tuberculosis, and measures for its prevention and control. Clinical
Guideline 33. National Institute for Clinical Excellence, London, 2006.

3 Richeldi L, Ewer K, Losi M, Roversi P, Fabbri LM, Lalvani A. Repeated tuberculin testing does not induce false positive ELISPOT results. Thorax 2006; 61: 180.

4 Cauthen GM, Snider DE Jr, Onorato IM. Boosting of tuberculin sensitivity among Southeast Asian refugees. Am J Respir Crit Care Med 1994; 149: 1597-1600.

5 Thompson NJ, Glassroth JL, Snider DE Jr, Farer LS. The booster phenomenon in serial tuberculin testing. Am Rev Respir Dis 1979; 119: 587-597.

\title{
Macrolides and bronchiolitis in infants
}

\section{To the Editors:}

In a recent issue of the European Respiratory Journal, TAHAN et al. [1] presented their results on clarithromycin therapy in respiratory syncytial virus (RSV) bronchiolitis in 12 infants aged $\leqslant 7$ months, compared with nine controls. They concluded that clarithromycin had a beneficial effect assessed by: the length of hospital stay; the need for oxygen therapy; the need for $\beta_{2}$-agonist treatment; and the rate of readmission to hospital within the subsequent 6 months [1]. The authors explained their findings in terms of suppression of airway hyperresponsiveness, since there are experimental in vitro data indicating that macrolides may inhibit cholinergic stimulation of airway smooth muscle [2]. In addition, macrolides are known to have various anti-inflammatory effects [3]. Supporting the effects on airway inflammation and responsiveness, the 3-week clarithromycin treatment was associated with decreases in plasma interleukin (IL)-4, IL-8 and eotaxin concentrations [1].

Three questions are raised when reading the study by TAHAN et al. [1]. First, only one out of 12 children in the clarithromycin group, compared with four out of nine in the placebo group, was readmitted. However, this difference is not, at least when calculated with my computer, statistically significant. In addition, statistical calculations may not be justified when the numbers of cases are so small. Secondly, the need for $\beta_{2^{-}}$ agonists may not be a useful outcome measure, since these drugs are rarely effective in infantile bronchiolitis [4]. Thirdly, RSV antigen detection was the only microbiological method available. Normal white blood cell counts and C-reactive protein concentrations do not rule out infections caused by atypical intracellular bacteria, such as Bordetella pertussis, Chlamydia trachomatis and Simkania negevensis. There are two recent studies reporting that mixed RSV and $B$. pertussis infections are common in nonvaccinated infants [5, 6]. In some populations, $S$. negevensis involvement seems to be common in RSV bronchiolitis [7, 8].

Thus, the beneficial effects of clarithromycin in the acute phase of respiratory syncytial virus bronchiolitis may have been based on the coexistence of atypical bacteria. Clinically, the beneficial effects were marginal; on average, the duration of need for supplementary oxygen and the length of hospital stay decreased by 1.5 days [1]. As TAHAN et al. [1] stated, respiratory syncytial virus bronchiolitis is the most common lower respiratory tract infection in infancy. Due to the harmful effects of large-scale antibiotic use in infants, macrolide treatment, even if associated with some anti-inflammatory or bronchial reactivity decreasing effects, should be restricted only to the cases with proven or presumptive atypical bacterial aetiology of infection.

\section{Korppi}

Dept of Paediatrics, Tampere University and University Hospital, Tampere University, Tampere, Finland.

\section{STATEMENT OF INTEREST}

A statement of interest for M. Korppi can be found at www.erj.ersjournals.com/misc/statements.shtml

\section{REFERENCES}

1 Tahan F, Ozcan A, Koc N. Clarithromycin in the treatment of RSV bronchiolitis: a double-blind, randomised, placebocontrolled trial. Eur Respir J 2007; 29: 91-97.

2 Labro MT. Anti-inflammatory activity of macrolides: a new therapeutic potential? Antimicrobial Chemother 1998; 41: 37-46.

3 Culic O, Erakovic V, Parnham M. Anti-inflammatory effects of macrolide antibiotics. Eur J Pharmacol 2001; 249: 209-229.

4 American Academy of Pediatrics Subcommittee on Diagnosis and Management of Bronchiolitis. Diagnosis and management of bronchiolitis. Pediatrics 2006; 118: 1774-1793.

5 Crowcroft NS, Booy R, Harrison T, et al. Severe and unrecognised: pertussis in UK infants. Arch Dis Child 2003; 88: 802-806.

6 Korppi M, Hiltunen J. Pertussis is common in nonvaccinated infants hospitalized for RSV infection. Pediatr Inf Dis J 2007; 26: 316-318. 
7 Kahane S, Greenberg D, Friedman M, Haikin H, Dagan R. High prevalence of "Simkania Z", a novel Chlamydia-like bacterium, in infants with acute bronchiolitis. I Infect Dis 1998; 177: 1425-1429.

8 Greenberg D, Banerji A, Friedman M, Chiu C-H, Kahane S. High rate of Simkania negevensis among Canadian Inuit infants hospitalized with lower respiratory tract infections. Scand J Infect Dis 2003; 35: 506-508.

DOI: 10.1183/09031936.00001907

\section{From the authors:}

We would like to thank M. Korppi for his comments regarding our recently published study on the use of clarithromycin in the treatment of respiratory syncytial virus (RSV) bronchiolitis [1].

RSV is the most common cause of upper and subsequent lower respiratory tract infection in children and it is most severe in children aged 8-30 weeks [2]. Despite many attempts to find effective treatments for patients with RSV bronchiolitis, no consistently effective therapy has yet been described. Since RSV infection initiates an immune inflammatory response that may produce long-lasting harmful effects, in our study we hypothesised that we could modify the course of the disease and prevent wheezing after bronchiolitis by administering macrolides (due to their anti-inflammatory effect) to infants during an acute episode of RSV bronchiolitis. Despite the small number of children in each group, the results of the study were exciting for us. This is important, as, to date, there has been no effective therapy for RSV bronchiolitis. Our results should encourage the undertaking of further studies to confirm the use of clarithromycin in RSV bronchiolitis, especially in infants aged $<6$ months who present with severe disease.

In our study, Bordetella pertusis was not investigated since all subjects tested positive for RSV and presented normal leukocyte counts, with leukocytosis $\left(15,000-100,000\right.$ cells $\left.\cdot \mathrm{mm}^{-3}\right)$ being characteristic of B. pertusis infection [3].

We did not investigate Simcania negevensis or Chlamydia trachomatis. Although in some populations the involvement of $S$. negevensis seemed to be common in association with RSV bronchiolitis [4, 5], results of one study [6] did not reveal any significant difference in the prevalence of $S$. negevensis infection between children with bronchiolitis and control subjects. In that study of 188 patients and 110 healthy control subjects, S. negevensis serological assays were positive in $18 \%$ of patients compared with $29 \%$ of control subjects [6].

We did not investigate $C$. trachomatis but we know that pneumonia due to $C$. trachomatis develops in 10-20\% of infants born to females with chlamydial infection. C. trachomatis pneumonia of infancy has a very characteristic presentation and auscultation reveals rales while wheezing is uncommon. A distinctive laboratory finding is the presence of peripheral eosinophilia $\left(>400\right.$ cells $\left.\cdot \mathrm{mm}^{-3}\right)$ [7]. In our study group, only one child had eosinophilia.

The use of bronchodilator agents continues to be controversial. The results of the meta-analysis indicated that some children treated with bronchodilators might have a transient improvement in clinical score [8]. Although there is no evidence from randomised controlled trials to justify the routine use of bronchodilators, clinical experience suggests that, in selected infants, there is an improvement in the clinical condition after bronchodilator administration [9-12]. In our study, the infants received $\beta_{2}$-agonist treatment based on clinical parameters, including the presence of wheezing on auscultation of the chest or respiratory distress with retractions. Wheeze and chest tightness has traditionally been associated with enhanced bronchial responsiveness. Airway hyperresponsiveness appears to be one manifestation of the airway inflammation induced by RSV. It has been shown that a correlation exists between airway inflammation and the degree of airway hyperresponsiveness (as discussed in our paper). Following this, duration of the need for $\beta_{2}$-agonist treatment (even for minimal improvement in clinical condition) may provide some indication as to the degree of airway inflammation.

In the process of re-analysis of the data for readmission, we realised that there was a data entry error. Unfortunately, this changes the statistical significance in the readmission rate. In our study, five patients were readmitted to hospital with wheezing within 6 months of discharge: four (44\%) from the placebo group and one (8.3\%) from the clarithromycin group. Although the values were higher in the placebo group, this difference did not reach significance, which may be attributed to the small number of children in each group.

\section{F. Tahan}

Paediatric Allergy, Erciyes University School of Medicine, Kayseri, Turkey.

\section{STATEMENT OF INTEREST}

None declared.

\section{REFERENCES}

1 Tahan F, Ozcan A, Koc N. Clarithromycin in the treatment of RSV bronchiolitis: a double-blind, randomised, placebocontrolled trial. Eur Respir J 2007; 29: 91-97.

2 Openshaw PJ, Tregoning JS. Immune responses and disease enhancement during respiratory syncytial virus infection. Clin Microbiol Rev 2005; 18: 541-555.

3 Long SS. Pertusis (Bordetella pertusis and B. Parapertusis). In: Behrman RE, Kliegman RM, Jenson HB, eds. Nelson Textbook of Pediatrics. 17th Edn. Philadelphia, Saunders, 2003; pp. 908-912.

4 Kahane S, Greenberg D, Friedman M, Haikin H, Dagan R. High prevalence of "Simkania Z", a novel Chlamydia-like bacterium, in infants with acute bronchiolitis. J Infect Dis 1998; 177: 1425-1429.

5 Greenberg D, Banerji A, Friedman MG, Chiu CH, Kahane S. High rate of Simcania negevensis among Canadian Inuit infants hospitalized with lower respiratory tract infections. Scand J Infect Dis 2003; 35: 506-508.

6 Kumar S, Kohlhoff SA, Gelling M, et al. Infection with Simcania negevensis in Brooklyn, New York. Pediatr Infect Dis J 2005; 24: 989-992. 